\title{
Studi Perencanaan Manajemen Sumber Daya Manusia Tenaga Pendidik di SD Islam Palembang
}

\author{
Prasetyo Budi Utomo', Mulyadi Eko Purnomo² Mgs.Nazarudin ${ }^{3}$ \\ ${ }^{1}$ SMP Negeri 10 Palembang, Sumatera Selatan, Indonesia \\ 2Universitas Islam Negeri Raden Fatah Palembang, Sumatera Selatan, Indonesia \\ ${ }^{3}$ Universitas Sriwijaya, Palembang, Indonesia \\ prasetyo.budiutomo123@gmail.com
}

\begin{abstract}
This study aims to explain: how the planning, recruitment, selection and placement, training and development, evaluation, compensation, supervision and constraints in the development of human resources for educators at SD Islam Fatimah Palembang. The research methodology used is a qualitative descriptive approach. Data collection techniques with observation, interviews and documentation. The analysis used data reduction, display and data verification. The results of the study are: planning for selection of prospective educators, recruitment planning systems, planning for training and human resource development as an effort to improve the quality of improving the quality of education, evaluations carried out using three stages, namely monthly evaluation, mid-semester and year-end evaluation. the provision of compensation and provision of allowances can increase the motivation for the performance of educators. The supervision system is carried out by setting standards, supervision, overcoming obstacles that are still faced in the planning process of Human Resources for Educators regularly.
\end{abstract}

Keywords: Planning, human resources, education, quality.

\begin{abstract}
Abstrak. Penelitian ini bertujuan untuk menjelaskan: bagaimana perencanaan, rekrutmen, seleksi dan penempatan, pelatihan dan pengembangan, evaluasi, kompensasi, pengawasan dan kendala dalam pengembangan sember daya manusia tenaga Pendidik di SD Islam Fatimah Palembang. Metote penelitian yang digunakan dengan pendekatan deskriptif kualitatif. Teknik pengumpulan data dengan observasi, wawancara dan dokumentasi. Analisis digunakan reduksi data, display dan verifikasi data. Hasil penelitian adalah: perencanaan seleksi terhadap calon Pendidik, sistem perencanaan perekrutan, Perencanaan pelatihan dan pengembangan SDM sebagai upaya untuk meningkatkan kualitas meningkatkan mutu pendidikan, evaluasi yang dilakukan dengan menggunakan tiga tahap, yaitu evaluasi bulanan, tengah semester dan evaluasi akhir tahun. pemberian kompensasi,dan pemberian tunjangan dapat meningkatkan motivasi kinerja para pendidik, Sistem pengawasan dilakukan dengan penentuan standar, supervise,mengatasi kendalakendala yang masih dihadapi dalam proses perencanaan SDM Manusia tenaga Pendidik secara berkala.
\end{abstract}

Kata Kunci: Perencanaa, SDM, pendidikan, Mutu

\section{PENDAHULUAN}

Era globalisasi menyebabkan lingkungan organisasi bersifat dinamis dan menciptakan situasi yang kompetitif. Persainganantar organisasi kini tidak hanya melibatkan persaingan bukti fisik ataupunmodal, melainkan persainganatas personelatau sumber daya manusia yang dimiliki. Hal ini menyebabkan sumber daya manusia merupakan factor strategis dan menjadi tolak ukur kesuksesan sebuah organisasi. Bahkan lebih jauh, sumber daya manusia dapat menjadi keunggulan kompetitif yang dimiliki sebuah 
organisasi. Merencanakan segala sesuatu juga merupakan konsep yang diajarkan dalam Islam. Rasulullah SAW bersabda: "Barang siapa menjadi orang yang selalu merencanakan setiap usahanya, maka ia akan diampuni oleh Allah" (HR Thabrani). Beberapa ayat Al-Qur'an yang mengajarkan untuk mempersiapkan (perencanaan) untuk hariesok.Urgensi sebuah perencanaan, untuk dapat memposisikan suatu sumber daya manusia yang sesuai pada posisi dan waktu yang tepat. Perencanaan juga merupakan sunatullah sebab alam dan seisinya serta segala yang menimpanya telah direncanakan oleh Allah SWT sebelumnya sehingga sistem alam mampu berjalan secara otomatis dengan baik bertahan hingga sekarang bahkan hingga kiamat tiba (Winarti, 2018).

Menurut Sule dan Ernie Trisnawati Manajemen sumber daya manusia adalah penerapan manajemen berdasarkan fungsinya untuk memperoleh sumber daya manusia yang terbaik bagi bisnis pendidikan yang kita jalankan dan bagaimana sumber daya manusia yang terbaik tersebut dapat dipelihara dan tetap bekerja bersama kita dengan kualitas pekerjaan yang senantiasa konstan ataupun bertambah (Sule, 2005).

Perencanaan SDM yang baik dengan cara memproyeksikan hasil analisis informasi yang diperolehnya. Peramalan biasanya untuk masa 5 tahunyang akan datang. Apabila ramalan-ramalannya mendekati kebenaran, rencana itu baik dan benar karena ia dapat membaca situasi masa yang akan datang dengan baik. Tujuan peramalan antara lain meramalkan kebutuhan dan persediaan tenaga kerja yang ada, meramalakan kemajuan pendidikan dan tekhnologi sehingga harus dilaksanakan pelatihan dengan kurikulum yang tepat, meramalkan kemajuan pendidikan dan meningkatkan kemampauan SDM, meramalkan kebutuhan akan jenis-jenis kecakapan yang berlainan dan jenis SDM pada masa yang akan datang, meramalkan kebijaksanaan perubahan pemerintah, seperti usia, UMR, dan jam kerja (Hartanto, 2016).

SD Islam Fatimah Palembang merupakan lembaga pendidikan yang memiliki potensi sangat baik, di tinjau dari segi letaknya yang strategis,memiliki gedung dan sarana prasarana yang memadai ,ditambah juga dengan pendidik yang mengajar disekolah tersebut memiliki disiplin dan dedikasi yang cukup baik terhadap tugasnya sebagai pendidik, ini dibuktikan dengan lulusan dari SD tersebut bayak diterima di Pondok Pesantren dan sekolah Negeri. Dari uraian di atas peneliti ingin meneliti bagaimana SD Islam Fatimah Palembang dalam melaksanakan perencanaan SDM pendidiknya. Meski demikian Berdasar hasil observasi pada awal November 2018 yang dilakukan di SD Islam Fatimah Palembang, diketahui bahwa masih banyak Guru yang mengajar tidak sesuai dengan kualifikasi pendidiknya. Hal ini 
(Studi Perencanaan Manajemen Sumber Daya Manusia Tenaga Pendidik Di SD Islam Palembang)

$\overline{\text { membuktikan bahwa perecanaan Sumber Daya Manusia yang direkrut oleh }}$ pihak sekolah belum berdasarkan prosedur yang benar dan masih banyak yang harus diperbaiki. Berdasarkan Permendiknas Nomor 16 Tahun 2007 tentang Standar Kualifikasi Akademik dan Kompetensi Guru pada jenjang SD/MI yaitu harus memiliki kualifikasi akademik pendidikan minimum Diploma IV (D-IV) atau Sarjana (S1) dalam bidang kependidikan SD/MI (DIV/S1 PGSD/PGMI) atau psikologi yang diperoleh dari program studi yang terakreditasi (Pemerintah, 2019). Berdasarkan permasalahan yang munculpada perencanaan Sumber Daya Manusia di SD Islam Fatimah Palembang, masih banyak tenaga Pendidik yang kurang berkompeten di bidangnya. Oleh karena itu, dilakukan penelitian yang berjudul Studi Perencanaan Manajemen Sumber Daya Manusia Tenaga Pendidikan di SD Islam Palembang.

\section{KAJIAN LITERATUR}

Perencanaan sumber daya manusia adalah suatu perencanaan yang sistematis tentang perkiraan kebutuhan dan pengadaan pegawai. Dengan demikian ada empat kegiatan yang harus dilakukan oleh perencanaan sumber daya manusia yaitu: menginvestasikan persediaan sumber daya manusia, memprediksi sumber daya manusia, menyusun rencana-rencana sumber daya manusia, memonitor dan mengevaluasi. Sutrisno (2012:33) perencanaan manajemen personalia atau yang lebih dikenal dengan sebutan manajemen sumber daya manusia (MSDM) adalah sebagai seleksi, perencanaan pengembangan, penggunaan, dan pemeliharaan sumber daya manusia oleh sebuah organisasi. Manajemen Sumber Daya Manusia (MSDM) adalah segala yang berkaitan dengan pengakuan pada pentingnya tenaga pendidik pada sekolah sebagai sumber daya manusia yang vital, yang memberikan sumbangan terhadap tujuan visi dan misi sekolah, serta memanfaatkan fungsi, dan kegiatan yang menjamin bahwa sumber daya manusia dimanfaatkan secara efektif adil demi kemaslahatan umat manusia dan individu (Sutrisno, 2012).

Perencanaan adalah pemilihan tujuan jangka pendek, dan jangka panjang serta merencanakan taktik dan strategi untuk mencapai tujuan tersebut. Dalam suatu organisasi perencanaan memiliki posisi penting dari langkah- langkah berikutnya, kematangan dan kesalahan dalam perencanaan mampu memberi pengaruh positif dan negative pada masa yang akan datang,sehingga suatu perencanaan yang di buat selalu memikirkan dampak jangka panjang yang mungkin akandi alami (Fahmi, 2017). Perencanaan SDM adalah menganalisis kebutuhan tenaga kerja di masa depan. Dalam langkah ini, berbagai variabel SDM seperti pengurangan SDM, lowongan yang akan 
dibuka, promosi pekerjaan, transfer karyawan (Daniel, 2018). Indonesia unggul akan dapat dicapai bila kita mempersiapkan secara sungguh-sungguh dan bersinergi dalam pembangunan sumber daya manusia, agar dapat bergerak cepat memenangkan persaingan dan diperhitungkan oleh negaranegara maju dunia (Cahyono, 2020).

Guru yang berkompeten dalam mendidik anak didik mampu melaksanakan tugas yaitu menyerahkan kebudayaan kepada anak didik berupa kepandaian, keterampilan, dan pengalaman, yang membuat peserta didik lebih berkembang, membentuk kepribadian anak yang harmonis, sesuai cita-cita dasar negara kita Pancasila, menyiapkan anak menjadi warga negara yang baik sesuai undang-undang pendidikan yang merupakan keputusan MPR, sebagai perantara dalam belajar, guru adalah pembimbing untuk membawa anak didik ke arah kedewasaan, guru sebagai penghubung antara sekolah dan mesyarakat yang nantinya akan hidup dan bekerja mengabdikan diri dalam masyarakat, dengan demikian anak harus dilatih serta dibiasakan di sekolah dibawah pengawasan guru, sebagai penegak disiplin,guru menjadi contoh dalam segala hal, tata tertib dapat berjalan bila guru dapat menjalankan lebih dahulu. guru sebagai administrator dan manajer, pekerjaan guru sebagai suatu profesi maka pekerjaan tersebut harus benar-benar dikerjakan secara professional, guru sebagai perencana kurikulum, guru sebagai pemimpin untuk anak didiknya, guru sebagai seponsor dalam kegiatan anak-anak didiknya.

Perencanaan Penilaian atau Evaluasi tenaga pendidik dan kependidikan adalah usaha-usaha yang dilakukan untuk mengetahui secara formal maupun informal untuk mengetahui hal-hal yang menyangkut pribadi, status, pekerjaan, prestasi kerja, maupun perkembangan para pendidik di sekolah sehingga dapat dikembangkan dan dipertimbangkan nilai objektif dalam mengambil tindakan terhadap seorang tenaga sekolah (Minarti, 2011).

Peran control dari Pimpinanefek yang positif baik secaralangsung maupun tidak langsung terhadap kepuasan kerjaperan kepemimpinan secaralebih umum dapat dimanifestasikan dalam berbagai cara seperti meneliti seberapa baik hasil kerja dan kinerja para pegawai, memberikan nasihat dan bantuan kepada individu, dan berkomunikasi dengan rekan kerja baik secara personal maupun dalam konteks pekerjaan. Hal ini dapat dilihat dari indicator yang menunjukan kepala sekolah mampu mengkoordinir konponen sekolah untuk mencapai tujuan sekolah (Setyaningsih, 2018).

Derasnya arus perubahan membawa konsekuensi bagiorganisasi untuk selalu mengantisipasi dan harus mampu menyesuaikan dengan perubahan yang terjadi. Dalam konteks ini perencanaan SDM akan menjadi lebih penting 
(Studi Perencanaan Manajemen Sumber Daya Manusia Tenaga Pendidik Di SD Islam Palembang)

bagi organisasi, karena globalisasi teknologi baru dan proses retrukturisasi organisasi selalu membayangi kehidupan organisasi. Organisasi yang tidak didukung oleh pendidik yang sesuai dari aspek kualitas, strategi dan operasional yang baik, maka dapat dipastikan organisasi tersebut akan sulit dipertahankan dan dikembangkan eksistensinya dimasa yang akan datang (Sunarta, 2016).

\section{METODE PENELITIAN}

Jenis penelitian ini adalah penelitian lapangan (field research) dengan pendekatan kualitatif studi kasus. Dalam hal ini penulis menekankan pada penelitian lapangan field research yang bersifat deskritif analitik yang menggunakan pendekatan kualitatif yaitu uraian naratif suatu proses tingakah laku subjek yang sesuai dengan masalah yang diteliti. Jadi penelitian ini termasuk jenis penelitian deskritif kualitatif, yaitu penelitian yang berusaha menggambarkan, menguraikan dan menjelaskan mengenai. Studi tentang perencanaan dan pembinaan sumber daya manusia pendidikan di SD Islam Fatimah Palembang (Sugiyono, 2013).

Penelitian kualitatif adalah kontruktitisme yang berasumsi bahwa kenyataan itu berdimensi jamak yang berarti mempunyai penafsiran yang lebih luas dan lebih beragam berdasarkan pengalaman dan latar belakang seorang penelitinya, interaktif dan suatu pertukaran pengalaman yang diinterprestasikan oleh setiap individu. Penelitian kualitatif percaya bahwa kebenaran adalah dinamis dan dapat ditemukan melalui penelaahan terhadaporang-orangmelaluiinteraksinya dengan situasi social mereka (Sukmadinata, 2012).

Analisis data merupakan suatu proses yang mengatur urutan data - data, lalu mengorganisasikannya ke dalam suatu pola dan kategori, kemudian satuan uraian dasar. Berdasarkan urutan permasalahannya, peneliti akan melakukan beberapa tahapan berikut dalam menganalisa data penelitian ini. Analisis data kualitatif dilakukan apabila data empiris yang diperoleh adalah data kualitatif berupa kumpulan berwujud kata-kata dan bukan rangkaian angka serta tidak dapat disusun dalam kategori-kategori/ struktur klasifikasi. Data bisa saja dikumpulkan dalam aneka macam cara (observasi, wawancara, intisari dokumen, pita rekaman) dan biasanya diproses terlebih dahulu sebelum siap digunakan (melalui pencatatan, pengetikan, penyuntingan, atau alih-tulis), tetapi analisis kualitatif tetap menggunakan kata-kata yang biasanya disusun ke dalam teks yang diperluas dan tidak menggunakan perhitungan matematis atau statistika sebagai alat bantu analisis. 


\section{HASIL DAN PEMBAHASAN}

\section{A.Perencanaan MSDM Tenaga Pendidik di SD Islam Fatimah Palembang.}

Terdapat dua faktor yang turut mempengaruhi sebuah perencanaan SDM suatu organisasi di SD Islam Fatimah Palembang, Nawawi mengemukakan faktoreksternal yangdapatberpengaruhpadaperencanaan SDM yang dilakukans eperti ekonomi nasional maupun global, sospolkum, teknologi, dan faktor pesaing. Keadaan ekonominasional maupun global secara keseluruhan turutmempengaruhi rencana stratejik maupun rencana operasional organisasi dan tentu juga dibutuhkan adanya penyesuaian pada perencanaan SDM.Kondisi dan produk sosial, politik dan hukum sangat berpengaruh terhadap kegiatan sebuah seperti undang-undang tenaga kerja yang berpengaruh pada kegiatan perencanaan SDM. Kemajuan ilmu pengetahuan juga berpengaruh pada produktifitas dan kualitas sebuah organisasi. Makin tinggi kemajuan teknologi yang diadaptasi maka harusada penyesuaian perencanaan SDM yang dimaksudkan mendapatkan kualifikasi SDM yang sesuai dengan karakteristik teknologi tersebut. Dalam era globalisasi yang kompetitif maka setiap organisasi dihadapkan pada tantangan persaingan yang berat. Untuk dapat bertahan maka organisasi membutuhkan SDM yang kompetitif pula. Persaingan untuk mendapatkan SDM yang berkualitas juga dapat terjadi. Maka dari itu perencanaan SDM sebuah organisasi menjadi sangat penting untuk dipersiapkan.

Disamping itu, Sedamayanti mengemukakan factor internal yang turut mempengaruhi seperti rencana stratejik dan rencana operasional organisasi, anggaran untuk SDM, peramalan pembiayaan, pengembangan organisasi, desain organisasi dan desain pekerjaan. Kemampuan sebuah organisasi dalam menyediakan anggaran untuk memperkejakan SDM yang sesuai dengan kebutuhan, sangat besar pengaruhnya terhadap perencanaan SDM. Perencanaan SDM tentu harus disesuaikan dengan kemampuan financial organisasi. Peramalan erat hubungannya dengan faktor anggaran yang telah disebut sebelumnya. Pengembangan yang dilakukan organisasi tentu akan mempengaruhi kebutuhan akan SDM yang akan dibutuhkan di masa mendatang maupun SDM yang telah dimiliki organisasi saat ini. Baik desain organisasi maupun desain pekerjaan adalah hasil penerjemahan rencana strategik dan rencana operasional agar organisasi berjalan efektif efisien. Bagaimana pemimpin mendesain organisasi dan mendesain pekerjaan, secara langsung berpengaruh pada perencanaan SDM sebuah organisasi. Disamping faktor-faktor tersebut baik faktor eksternal maupun faktor internal juga terdapat faktor yang dapat mempengaruhi perencanaan SDM sebuah organisasi diantaranya factor ketenaga kerjaan, demografi, 
(Studi Perencanaan Manajemen Sumber Daya Manusia Tenaga Pendidik Di SD Islam Palembang)

supervise yang dilakukan, prestasi kerja, pasar tenaga kerja dan sebagainya (Winarti, 2018).

\section{Perencanaan Rekrutmen}

Rekrutmen adalah putusan sumber daya manusia (SDM) berupa banyak dibutuhkan, kapan dibutuhkan, serta pengetahuan keterampilan, kemampuan khusus yang dimiliki. (Silalahi, 2009) Penarikan (rekrutmen) pegawai merupakan suatu proses atau tindakan yang dilakukan oleh organisasi untuk mendapatkan tambahan pegawai melalui beberapa tahapan mencakup identifikasi dan evaluasi sumber-sumber penarikan tenaga kerja, menentukan kebutuhan tenaga kerja, proses seleksi, penempatan, dan orientasi tenaga kerja. Penarikan pegawai bertujuan menyediakan pegawai yang cukup agar manajemen dapat memilih karyawan yang memenuhi kualifikasi yangmereka perlukan (Enambe, 2015).

Analisis Kebutuhan SDM Tenaga Pendidik. Sebelum rekrutmen dilaksanakan maka Yayasan SD Islam Fatimah melakukan an alisis kebutuhan. Analisis ini dilakukan untuk mendapatkan data mengenai formasi atau posisi apa yang kosong.Dan untuk menentukan persyaratan yang perlu dimiliki oleh calon pendidik.Kemudian baru masuk tahap penyusunan perencanaan untuk rekrutment. Persiapan Rekrutmen, Setelah hasil analisis kebutuhan guru sudah jelas maka kegiatan yang akan di persiapkan pihak Yayasan adalah melaksanakan proses rekrutmen, dengan cara penentuan waktu dan biaya dalam penarikan SDM, penetapan prosedur penerimaan tenaga pendidikan, penetapan kualifikasi pelamar, pengajuan permohonan lamaran pekerjaan dengan kelengkapan administrasi.

\section{Perencanaan Pelaksanaan Rekrutmen di Yayasan SD Islam Fatimah Palembang.}

Persiapan Seleksiperencanaan atau persiapan seleksi yang dilakukan sebelum melakukan seleksi adalah (a) Penetapan Tim seleksi (b) menyiapkan instrument penilaian, dan (c) persiapan tempat dan waktu seleksi. Pelaksanaan Seleksi yaitu Seleksi Administrasi dan Wawancara awal yang meliputi (a) Tes kepribadian( b) Tes Keilmuan atau Wawasan.(c) Tes Baca alQur'an dan Hafalan. Tes Micro Teaching, Micro Taeching adalah untuk mengetahui kemampuan dalam mengajar. Adapun aspek yang dinilai (a) Penyampaian Materi (b) PenguasaanMateri (c) Penggunaan Media IT(d) KemampuanBahasa (e)Penampilan. Tes Wawancara Akhir, Wawancara akhir adalah untuk mengetahui serta menilai secara langsung tentang kepribadian, motivasi pelamar, tujuan melamar dan permintaan gaji. Dalam 
tahap akhir juga temasuk penanda tanganan kontrak kerja antara calon pegawai yang diterima dengan pihak Yayasan Keputusan Seleksi,Pertimbangan sebagai nilai lebih kemampuan pelamar sebagai pendidikan adalah berkas yang disertakan pelamar di surat lamaran misalnya prestasi yang diraih, pengalaman kerja, dan dokuman lain yang mendukung, Dari penjelasan tersebut tegas dapat kita ambil kesimpulan bahwa, Yayasan SD Islam Fatimah memilikiprosedur yang sistematis dalam seleksi.

\section{B. Perencanaan Pengembangan Kompetensi SDM Pendidik SD Islam Fatimah Palembang Perencanaan Program Pengembangan.}

Dalam hal ini pihak Yayasan SD Islam Fatimah membuat rencana program untuk pengembangan SDM tenaga pendidik sudah dilakukan dengan baik, mengacu pada visi dan misi dari Lembaga dan perkembangan pendidikan, Perencanaan yang dibuat disusun berdasarkan kebutuhan, baik rencana jangka pendek,jangka menengah dan jangka panjangya. Meski demikian ada juga perencanaan yang tidak disusun secara periodik, karena ada beberapa program yang bersifat insidental dan hanya mengikuti program yang dilakukan oleh pemerintah saja.

\section{Perencanaan Program Pengembangan Jangka Pendek.}

Dalam perencanaan pengembangan SDM pendidik jangka pendek Yayasan SD Islam Fatimah memiliki beberapa program yang sudah dijalankan. Adapun program-program pengembangan adalah sebagai berikut yang pertama adalah Kegiatan Supervisi. Kegiatan Supervisi merupakan kegiatan pengawasan dan penilaian kinerja yang menyangkut proses belajar mengajar di sekolah. Kegiatan superfisi di SD Islam Fatimah di lakukan kepala sekolah setiap tiga bulan sekali untuk melihat dan mengecek kelengkapan programprogram mengajarnya yang menyangkut persiapan mengajarnya seperti program semester, program tahunannya, dan RPP. Supervisi yang di lakukan pengawas tingkat korwil atau pengawas dari instansi pemerintah yaitu yang terkait langsung dari Dinas Pendidikan Kota Palembang dilakukan setiap satu semester sekali. Yang kedua, mengikutsertakan Kegiatan Ilmiah (diklat, seminar, workshop). Yang ketiga, mengadakan Kerjasama Dengan Berbagai Pihak. Yang ke empat Pengajian Bulanan, Kegiatan pengajian bulanan ini diadakan rutin setiap sebulan sekali dengan kegiatan yang di lakukan secara berkelompok untuk meningkatkan bacaan dan hapalan Al-Quran, kegiatan tausiah, dan kegiatan penanaman Ahklaq mulia lainya yang bisa 
(Studi Perencanaan Manajemen Sumber Daya Manusia Tenaga Pendidik Di SD Islam Palembang)

meningkatkan masalah pemahaman Agama pendidik Yayasan SD Islam Fatimah Palembang. Yang kelima Rapat Pembinaan dari Kepala Sekolah. Rapat pembinaanrutin bulanan ini bertujuan untuk melakukan pembinaan kepada seluruh guru terutama dalam capaian keberhasilan kegiatan KBM untuk mengevaluasi sejauh mana tingkat keberhasilan penyampaian materi ajar ataupun tingkat kehadiran para pendidik ketika dalam proses pembelajaranDan yang ke enam Pembinaan Secara Individu. Pembinaan ini adalah pembinaan yang dilakukan kepala sekolah ataupun dari pihak yayasan untuk mengetahui permasalahan secara mendalam yang di hadapi oleh para pendidik.

\section{Perencanaan Program Pengembangan Jangka Menengah.}

Yang Pertama adalah Studi Lanjut Studi lanjut yaitu dengan memberikan kesempatan pada tenaga Pendidik melalui peningkatan kualitas pendidikan yang dimiliki personil dengan cara melanjutkan ke jenjang yang lebih tinggi seperti kejenjang persamaan untuk PGSD bagi guru yang bukan dari latar belakang Pendidikan PGSD (S1) nya dan jenjang (S2). Berdasarkan data yang ada sampai pada tahun ajaran 2019/2020 ini sudah 96,88 \% orang guru yang memiliki kualifikasi pendidikan yang linier dengan jabatanya ,dan guru yang sudah sertifikasi sebesar 9,38 \% dan ini akan terus ditingkatkan sampai menjadi 100 \% karena guru-guru yang belum linier diharapkan dapat mengikuti program penyesuaian yang di laksanakanYang ke dua Study Banding Ke Sekolah Dasar Islam di Surakarta. Study Banding yang di lakukan SD Islam Fatimah Palembang ke beberapa Sekolah di Surakarta (solo) merupakan usaha untuk meningkatkan kualitas dan kuantitas SD Islam Fatimah setidaknya mencari gambaran secara umum bagaimana sekolahsekolah yang berbasis Islam yang ada di solo. Yang ke tiga Penyediaan Perpustakaan Yang lengkap.Perpustakaan merupakan tempat yang didalamnya terdapat segudang ilmu dan pengetahuan,maka dari itu fasilitas perpustakaan yang memadaijufa akan menambah keilmuan para pendidiknya jika ada kemauan untuk belajarYang ke empat Pemberian Tunjangan Kesejahteraan Kesejahteraan merupajkan factor penting di dalam sebuah pengabdian,kesejahteraan yang baik akan meningkatkanmotivasi pendidik untuk melaksanakan tugasnya dengan baik.(SDI Fatimah : 2019).

\section{Perencanaan Program Pengembangan Jangka panjang.}

Yang pertama Peningkatan Sarana Prasarana.Prasarana yang terus di kembangkan oleh SD Islam Fatimah adalah pembangunan ruang kelas,masjid,lapangan olah raga,hol untuk kegiatan keagamaan laboratorium 
computer,perpustakaan,dan laboratorium IPA.Sedangkan sarana lain yang tak kalah pentingnya juga yaitu sarana kegiatan yang diperlukan seperti peralatan olah raga, MTK,dan IPA .Yang kedua Peningkatan Akreditasi Sekolah. Akreditasi sekolah adalah evaluasi yang di lakukan oleh instansi terkait yaitu badan Akreditasi. Akreditasi untuk mengukur sejauh mana keberhasilan pembelajaran yang di lakukan SD Islam Fatimah secara menyeluruh yang meliputi delapan Standar yang harus disiapkan oleh sekolah yaitu:

1. Standar Isi

2. Standar Proses,

3. Standar Kompetensi Kelulusan

4. Standar pendidik dan kependidikan

5. Standar sarana dan prasarana

6. Standar pengelolaan,

7. Standar pembiayaan dan

8. Standar penilaian

SD Islam Fatimah sudah mendapatkan predikat Akreditasinya A ( Sangat baik). Yang ke tiga Wacana untuk berbasis ITDi era globalisasai ini SD Islam Fatimah terus meningkatkan kemampuan IT para pendidiknya dengan mengadakan pelatihan dan sosialisasi pengunaan kurikulum berbasis IT, apa lagi didalam kurikulum K 13 ini memang para pendidik di tuntut untuk dapat mengunakan teknologi.

\section{Perencanaan Evaluasi Program Pengembangan}

Dalam tahapan ini Program Evaluasi pengembangan, Seperti yang dipaparkan Ketua Yayasan bahwa Program yang Kami buat bertujuan untuk selalu mengupgrade kemampuan dan kelimuan pendidik, karena program yang kami buat juga belum dilaksanakan pada waktu yang lama,oleh karena itu pada saat ini, mungkin kami belum sampai pada tahap melihat efektif atau tidaknya program tersebut.

Dari hasil wawancara tersebut maka dapat disimpulkan bahwa evaluasi program perencanaan SDM pendidik ini belum dilakukan sepenuhnya dengan beberapa alasan, belum terealisasikan program dengan baik, instrument evaluasi dan keterbatasan waktu. Di lihat dari uraian mengenai program pengembangan yang ada di Yayasan SD Islam Fatimah sudah direalisasikan, akan tetapi ada sedikit kekurangan diantaranya perencanaan yang belum mendetail dan evaluasi program yang belum sepenuhnya terlaksana, tapi sejauh ini kualitas dari pendidik dapat dikatakan sudah cukup baik karena melalui proses seleksi yang baik.Di dalam 
(Studi Perencanaan Manajemen Sumber Daya Manusia Tenaga Pendidik Di SD Islam Palembang)

meningkatkan keberhasilan semua program memang sangatlah di butuhkan kerja sama,kepedulian, ,kesinambungan dan yang peling penting adalah keseriusan semua eleman yang terkait untuk melakukan tugasnya dengan baik penuh tangung (Deviana, 2019).

\section{Hambatan dan Tantangan Yang Dihadapi Dalam Perencanaan SDM Pendidik Di SD Islam Fatimah Palembang.}

\section{Hambatan dalam perencanaan SDM Pendidik di SD Islam Fatimah Palembang.}

Perencanaan sumber daya manusia merupakan suatu usaha untuk memulai proses awal dalam menjalankan suatu Organisasi, Perencanaan juga merupakan jaminan hasil akhir dalam suatu pekerjaan, maka dari itu suatu perencanaan harus benar-benar cermat dan harus benar-benar matang karena bersangkutan dengan hasil dimasa mendatang atau dimasa depan.

Didalam pembahasan sebuah perencanaan sumbe daya manusia, dapat digaris bawahi bahwasanya manusia yang dikelola dalam merencanakan sumber daya, maka dari itu harus lebih kita fahami mengenai permintaanpermintaan sumber daya manusia yang dibutuhkan. Adapun faktor-faktor yang termasuk didalam pemintaaan SDM diantaranya yaitu:

1. Faktor eksternal Perekonomian, Sosial, politik, hukum, Teknologi, dan Pesaing.

2. Faktor organisasiRencana strategis, Anggaran, Perakiraan penjualan dan produksi, Unit usaha baru, Perancangan organisasi dan pekerjaan.

3. Faktor tenaga kerja Pensiun, Pengunduran diri, Pemutusan hubungan kerja, Kematian, dan Cuti.

Hambatan yang di hadapi dalam perencanaan di SD Islam Fatimah Palembang adalah: Yang pertama yaituTujuan yang kurang tepat sasaran atau terburu- buru.Perencanaan yang terburu-buru dalam mencukupi kebutuhan tenaga pengajar ,ini yang sering terjadi,kenapa demikian karena terkadang kekurangan guru itu di sebabkan oleh keadaan yang tidak di perkirakan sebelumnya ,misalnya bayak guru yang di terima menjadi ASN,atau guru yang berhenti dan mengundurkan diri di karenakan hal-hal tertentu. Yang kedua Sistem anggaran dalam perekrutan. Perekrutan yang memadai dan berkualitas tentunya tidak bisa di pisahkan dari berapa besar biaya angaran yang disediakan dalam perekrutan tersebut.mengapa demikian karena untuk melakukan perekrutan tentunya memerlukan SDM atau orang yang professional dalam bidangnya. Yang ketiga Persaingan yang semakin Tajam.Semakin tingginya tututan masyarakat di dalam dunia pendidikan 
tentunya menjadi tantangan juga bagi pendidik SD Islam Fatimah untuk menunjukan dan mewujudkan sebagai sekolah yang berkualitas dan berdedikasi tinggi dalam mengasuh anak-anak didiknya. Yang ke empat Promosi dan Sosialisasi.Terbatasnya Promosi jasa Pendidikan yang di lakukan juga menjadi hambatan bagi perkembangan SD Islam Fatimah yang lebih besar lagi kedepanya Sistem angaran yang masih terbatas dalam pengembangan profesi.(Moh.Handoko, 2016)

\section{Tantangan Perencanaan SDM}

Perencanaan SDM dalam suatu organisasi Pendidikan akan dirasakan efektif atau tidaksangat tergantung pada kualitas dan jumlah informasi yang relevandantersedia bagi pengambilan keputusan. Dalam praktek pelaksanaan perencanaan SDM yang efektif, pada eraglobal seperti sekarang ini akan menghadapi tantangan yang tidak ringan. Salah satu tantanganyang harus dihadapi, antara lain.

1. Mempertahankan keunggulan kompetitif. Dalam persaingan yang keras, keunggulankompetitif menjadi tujuan setiap organisasi .Keunggulan kompetitif yangdiraih dandinikmati oleh organisasi hanya bersifat jangka pendek karena organisasi lain juga melakukan usaha untuk mencari dan meraih keunggulan kompetitif dengan strategi yangsama dengan yang kita lakukan. Sehingga tantangan dari perspektif SDM adalah membuat tstrategi-strategi yang menawarkan keunggulankompetitif yang dapat dipertahankan.

2. Menghindari konsentrasi berlebihan pada masalah-masalah harian. Kebanyakan para Pendidik lebih banyak mencurahkan hal-hal yang bersifat rutinitas dan berperspektif jangka pendek.Dalam konteks ini perencanaan SDM memiliki tantangan untuk masa datang dalammelahirkan orang-orang visioner yang mampu melihat gambaran masa depan secara integralmelebihi orang lain di sekitarnya.

3. Menyusun strategi - strategi SDM yangsesuai dengan karakteristikkarakteristik unik organisasi. Menjadi tugasdalam perncanaan SDM mendatang dalam menyusun strategi yang berbedadengan pesaing. Keunikan strategi Pendidikan dijalankan antar Sekolah tidak adayang sama persis, namun dalam menjaga strategi yang sukses dijalankan selama inimenjadi suatu hal yang sangat sulit sehingga mudah ditiru pesaing.

4. Menanggulangi perubahan lingkungan. Lingkunganyang kompetitif merupakantantangan bagi program perencaan, bukan saja dalam 
(Studi Perencanaan Manajemen Sumber Daya Manusia Tenaga Pendidik Di SD Islam Palembang)

bidang SDM tetapi dalam hal perencanaan pemasaran, dan penganggaran lainnya.

5. Menyita komitmen manajemen. Perencanaan SDM di tengah-tengah persaingan bisnis padasituasi ekonomi global saat ini, pencapaian tujuan-tujuan organisasi secara keseluruhan kurang optimal. Halini menjadi tantangan di masa datang dalam usahamemenangkan setiap persaingan.

6. Menterjemahkan rencana strategic ke dalam tindakan. Tantangan lain dalam pelaksanaan perencanaan SDM dan perencanaanstrategi Pendidikan adalah sering tidak adanya kesesuaianantara rencana yang bagus tetapi jelek dalam praktek. Dengan belajar dari keadaan ini,selayaknya pada masa datang sebelum rencana direalisasikan harus diuji dan kaji dulusehingga bisa memberikan jaminan keberhasilan perencanaan.

7. Mengakomodasika perubahan-perubahan. Tantangan terakhir dalam perencanaan SDM dan perencanaan strategi bisnis pendidikan adalah bagaimana semua rencana yang akan dilakukandapat menyesuaikan dengan dinamika jaman yang ada. Perencanaan yang tidak akomodatif,tidak lentur, tidak fleksibel dan tidak peka terhadap perkembanganpasar hanyaakan melahirkan kumpulanrencana yang sulit untukdirealisasikan (Sunarta, 2019).

Perencanaan bisa berjalan dan terlaksana dengan baik manakala SDM Tenaga Pendidik memiliki motivasi yang berkaitan dengan usaha dan dorongan yang timbul dari dalam diri seseorang dimana dilakukan untuk memenuhi semua tujuan yang diinginkan oleh seseorang sehingga mencapai ke arah tujuan yang ditujukan. Pendidik yang memiliki motivasi dalam bekerja akan membantu hasil kinerja tersebut. Motivasi kerja adalah dorongan untuk mengarahkan bawahan agar mau bekerja secara produktif untuk mewujudkan tujuan yang telah ditetapkan. ada tiga hal kategori kebutuhan individu, yaitu eksistensi (existence), keterhubungan (relatedness), dan pertumbuhan (growth). Teori ini mengemukakan kebutuhan manusia menjadi tiga kelompok yaitu :

1. kebutuhan eksistensi ini untuk kebutuhan dalam bertahan hidup, kebutuhan fisik;

2. kebutuhan keterhubungan adalah kebutuhan untuk berhubungan dengan kebutuhan untuk berinteraksi dengan orang lain;

3. kebutuhan pertumbuhan adalah kebutuhan yang berhubungan dengan pengembangan diri untuk menjadi produktif dan kreatif. 
Kesimpulan motivasi seseorang dapat dilihat dari kebutuhan hidup yang dimulai mencari kebutuhan yang lebih tinggi. Kuatnya keinginan memuaskan kebutuhan yang lebih tinggi apabila kebutuhan yang lebih rendah telah dipuaskan (Siswanto, 2016).

\section{KESIMPULAN}

Berdasarkan hasil penelitian, pengolahan dan analisa data yang telah penulis lakukan dari awal sampai pada akhir penelitian tersebut: Yang pertama Pelaksanaan Perencanaan Suber Daya Manusia (PSDM) Pada Yayasan SD Islam Fatimah Palembang sudah menunjukan indikatot-indikator yang efektif . Efektifitas Perencanaan SDM Pendidik,dalam upaya peningkatan kualitas dan profesionalitas tenaga pendidik di SD Islam Fatimah Palembang bisa di jadikan acuan atau pedoman dalam merencanakan keberhasilan dan terwujudnya para pendidik yang berkualitas,sehingga secara langsung juga mendorong kualitas dari sekolah secara keseluruhan. Yang ke dua Dalam upaya pengembangan sumber daya Tenaga Pendidiknya, Yayasan SD Islam Fatimah melakukan berbagai cara dan kiat khusus yang bertujuan menghasilkan tenaga Pendidik yang bermutu tinggi dan memiliki komitmen kuat terhadap lembaga. Dalam pengembangan mutu sumber daya tenaga Pendidik ada beberapa upaya yang telah dilakukan oleh Yayasan SD Islam Fatimah Palembang yaitu supervisi, kegiatan Ilmiah, mengadakan kerjasama dengan pihak lain, studi lanjut, penyediaan perpustakaan, dan pemberian tunjangan kesejahteraan.

\section{DAFTAR PUSTAKA}

Cahyono, E. (2020). Pembangunan sumber Daya Manusia (SDM) Menuju Indonesia Unggul. Journal setneg, 10 (2).

Daniel. (2018). Perencanaan Sumber Daya manusia. Ekonomi management, 23.

Enambe, R. (2015). Analisis Sistem Perencanaan Sumber Daya Manusia pada Kantor Dinas Kesehatan Kabupaten Tolikara Provinsi Papua. Unsrat, 4 (6).

Fahmi, I. (2017). Manajemen Sumber Daya Manusia. Bandung: CV Alvabeta. Fahmi, I. (2017). Manajemen Sumber Daya Manusia. Bamdung: CV.Alfabeta. Handoko, M. (2016). Perencanaan Sumber daya Manusia. Human Resourse Management , 1-2.

Hartanto. (2016). Perencanaan Sumber daya Manusia . Trading forex fbsindonesia.co.id, 5 . 
(Studi Perencanaan Manajemen Sumber Daya Manusia Tenaga Pendidik Di SD Islam Palembang)

Minarti. (2011). Mengelola lembaga Pendidikan Secara Mandiri. Yogyakarta:

Ruzz Media.

Setyaningsih, K. H. (2018). Pengaruh Motivasi Kerja, Budaya Organisasi,

Kepemimpinan Kepala Sekolah Terhadap Kepuasan Kerja dan Kinerja

Guru SMA Swasta di Palembang. El-Idare: Jurnal Manajemen

Pendidikan Islam, 4(1).

Siswanto, B. (2016). Pengaruh Motivasi kerja Dan Disiplin kerja Terhadap

Kinerja Karyawan. JIMS -Jurnal Ilmiah Manajemen Sumber Daya

Manusia, 78.

Sugiyono. (2013). Metode Penelitian Kuantitatif dan kualitatif. Bandung:

Alfabeta.

Sukmadinata. (2012). Metode Penelitian Pendidikan. Bandung: PT.Remaja

Rosdakarya.

Sule, E. T. (2005). Pengantar Managemen. jakarta: kencana.

Sunarta. (2016). Perencanaan Sumber Daya Manusia. Jurnal FISE, 6 (2).

Sunarta. (2019). Perencanaan Sumber Daya Manusia. FISE Universitas Negeri Yogyakarta, 10-11.

Sutrisno, E. (2012). Manajemen Sumber Daya Manusia. Jakarta: Prena Maedia Grup.

Winarti, E. (2018). Perencanaan Manajemen Sumber Daya Manusia Lembaga Pendidikan. Malang: Jurnal tarbiyatuna.

Winarti, E. (2018). Perencanaan Manajemen Sumber Daya Manusialembaga Pendidikan. Jurnal Tarbiyatuna, 3 (1), 2-3. 